\title{
METODE GRAVITASI UNTUK IDENTIFIKASI SESAR WELUKI DENGAN ANALISIS FIRST HORIZONTAL DERIVATIVE DAN SECOND VERTICAL DERIVATIVE
}

\author{
Desta Suci Fitriani ${ }^{\mathrm{a}}$, Sari Nur Atikah Putri ${ }^{\mathrm{b}}$, Ichwan Fauzan Putrajy ${ }^{\mathrm{c}}$ \\ Program Studi Geofisika, Fakultas Matematika dan Ilmu Pengetahuan Alam, Univeristas Indonesia, Kampus \\ UI Depok, 16424, Indonesia.

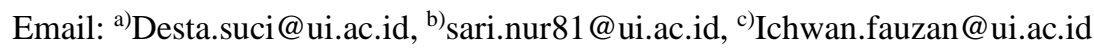

\begin{abstract}
Abstrak
Sulawesi dalam tatanan tektonik Indonesia berada pada daerah pertemuan tiga lempeng bumi (triple junction) yaitu Lempeng India Australia, lempeng Pasifik dan lempeng. Pertemuan ketiga lempeng ini membuat Pulau Sulawesi tersusun oleh tatanan tektonik yang kompleks. Salah satu sesar yang terbentuk akibat peristiwa ini yaitu Sesar Weluki. Penelitian ini bertujuan untuk identifikasi keberadaan dan jenis Sesar Weluki. Penelitian ini menggunakan data topografi dan free air anomaly dari satelit TOPEX. Data TOPEX kemudian dianalisis dengan First Horizontal Derivative (FHD) dan Second Vertical Derivative (SVD) menggunakan software Surfer 16. Analisis FHD digunakan untuk menentukan batas sesar sedangkan SVD digunakan untuk menentukan jenis Sesar Weluki. Berdasarkan pengolahan data menggunakan metode parasnis, densitas rata - rata batuan penyusun Sesar Weluki sebesar 2.4454 $\mathrm{gr} / \mathrm{cm}^{3}$. Berdasarkan peta kontur residual, strike Sesar Weluki memiliki orientasi Utara - Selatan. Hasil dari analisis SVD menunjukkan bahwa Sesar Weluki merupakan jenis sesar naik.
\end{abstract}

Kata-kata kunci: Gravitasi, First Horizontal Derivative, Second Vertical Derivative, fault.

\begin{abstract}
Sulawesi in the tectonic order of Indonesia is located at the confluence of three earth plates (triple junction) namely the Australian Indian Plate, the Pacific Plate, and the Eurasian plate. The confluence of these three plates makes Sulawesi Island composed of a complex tectonic setting. One of the faults formed from this event is the Weluki Fault in Central Sulawesi. This study aims to identify the existence and type of Weluki fault. This research uses topography and the Free Air Anomaly data from the TOPEX satellit. Then TOPEX data were analyzed using the First Horizontal Derivative (FHD) and Second Vertical Derivative (SVD) methods using Surfer 16. The FHD analysis was used to determine the fault bundary and SVD was used to determine the weluki fault type. Based on the results of data processing using the parasnis method, an average density of weluki fault rocks about $2.4454 \mathrm{gr} / \mathrm{cm}^{3}$. From the residual contours map, the strike orientation of Weluki Fault is North - South. The results of the SVD analysis show that the weluki fault has a reverse fault.
\end{abstract}

Keywords: Gravity, First Horizontal Derivative, Second Vertical Derivative, fault.

\section{PENDAHULUAN}

Sulawesi terletak pada zona pertemuan tiga lempeng benua (triple junction) yaitu Lempeng India Australia, Pasifik dan Eurasia [3]. Pertemuan ketiga lempeng tersebut membuat Pulau Sulawesi 
tersusun oleh tatanan teknonik yang kompleks [2]. Kompleksitas tatanan tektonik sulawesi dibuktikan oleh struktur geologi yang terbentuk, salah satunya yaitu sesar. Sesar - sesar yang terbentuk terdiri dari sesar yang masih aktif bergerak dan tidak bergerak lagi. Berdasarkan buku Peta Sumber dan bahaya Gempa Indonesia Tahun 2017 yang disusun Pusat Studi Gempa Nasional Kementerian PUPR, Sesar Weluki merupakan salah satu sesar aktif yang terbentuk akibat kompleksitas tatanan tektonik Pulau Sulawesi. Karena Sesar Weluki termasuk sesar mikro aktif, tidak menutup kemungkinan bahwa suatu saat sesar ini bisa menyebabkan terjadinya bencana gempa bumi. Oleh karena itu, penelitian ini bertujuan untuk mengetahui keberadaan dan jenis Sesar Weluki.

Metode yang digunakan untuk mengidentifikasi sesar ini yaitu metode geofisika. Metode geofisika adalah metode yang mempelajari fenomena kebumian dengan menggunakan prinsip prinsip fisika, salah satunya metode gravitasi. Metode gravitasi digunakan untuk mengidentifikasi dan memetakan struktur geologi, salah satunya adalah sesar berdasarkan variasi medan gravitasi yang disebabkan oleh perbedaan densitas batuan[5]. Pada penelitian ini, metode gravitasi digunakan untuk memetakan distribusi densitas bawah permukaan daerah Sulawesi Tengah. Pemetaan distribusi densitas dapat memberikan informasi tambahan mengenai anomali gravity di daerah penelitian. Keberadaan anomali gravity dapat diinterpretasikan sebagai struktur geologi berupa sesar.

\section{METODE PENELITIAN}

\section{Metode Pengambilan Data}

Data yang digunakan dalam penelitian ini adalah data yang diperoleh dari website https://topex.ucsd.edu/cgibin/get data.cgi. Posisi geografis wilayah penelitian ini berada pada $1.470^{\circ}-1.99^{\circ}$ LS dan $120.303^{\circ}-122.102^{\circ}$ BT. Data yang diperoleh dari TOPEX berupa data topografi dan free air anomaly (FAA). FAA merupakan data medan gravitasi yang telah mengalami koreksi pasang surut bumi, koreksi lintang, dan koreksi udara bebas.

\section{Metode Pengolahan Data}

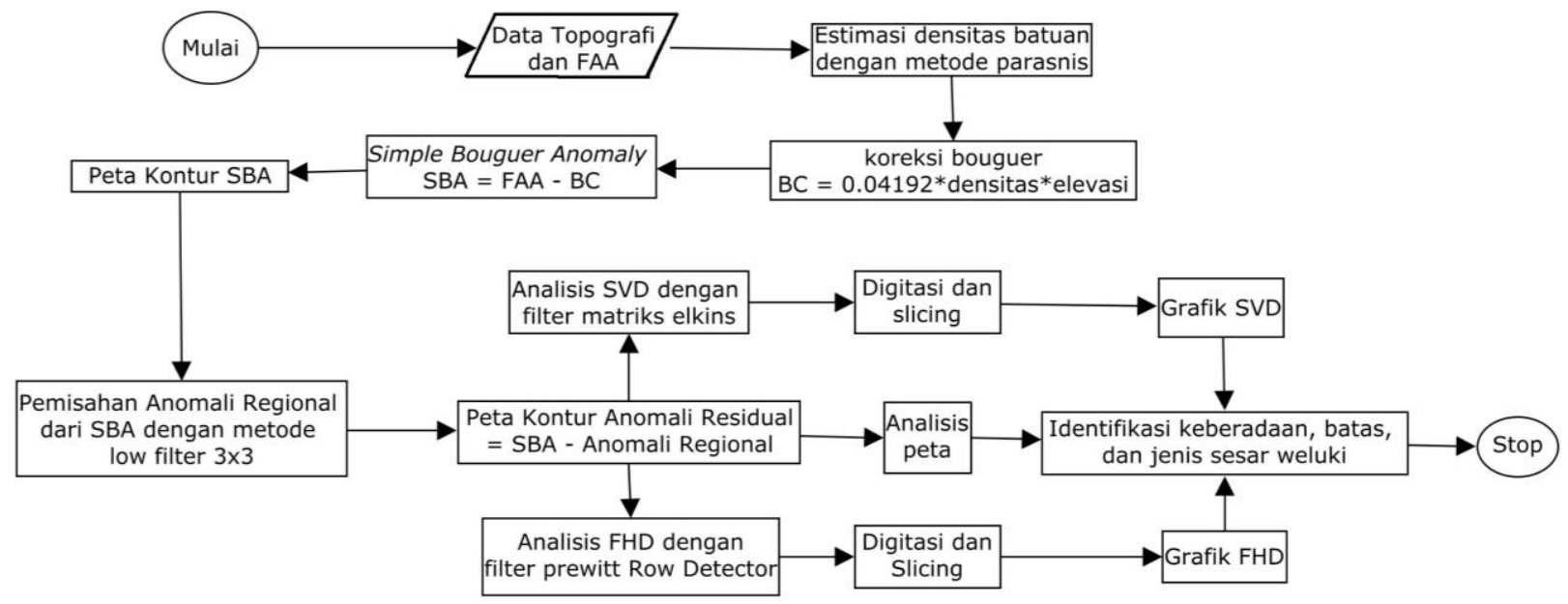

GAMBAR 1. Diagram alir pengolahan data

Data topografi dan FAA diolah menggunakan microsoft excel untuk mendapatkan nilai densitas rata - rata, Bouguer Correction, dan Simple Bouguer Anomaly. Densitas rata - rata batuan daerah penelitian dapat dicari menggunakan metode parasnis. Metode parasnis menggunakan persamaan regresi linear $\mathrm{y}=\mathrm{mx}+\mathrm{c}$ yang diturunkan dari persamaan anomali gravitasi (persamaan 1). Dimana sumbu y didapat dari nilai FAA $\left(g_{\text {obs }}-g_{n}+0,3086 h\right)$ dan sumbu x didapat dari ketinggian dikalikan dengan 0.04192. Kemiringan garis trend dari grafik tersebut merupakan densitas rata - rata batuan yang ada di daerah penelitian. 


$$
\begin{aligned}
& \Delta g=g_{\text {obs }}-g_{n}+0,3086 h-0,04192 \rho_{0} h \\
& g_{\text {obs }}-g_{n}+0,3086 h=0,04192 \rho_{0} h+\Delta g \\
& g_{\text {obs }}-g_{n}+0,3086 h=\rho_{0}(0,04192 h)+\Delta g
\end{aligned}
$$

Selanjutnya, parameter densitas digunakan untuk mencari koreksi bouger (BC) (persamaan 2). Koreksi bouguer berfungsi untuk menghilangkan efek massa diantara stasiun pengukuran dengan bidang datum. Kemudian FAA dikoreksi dengan koreksi bouguer untuk mendapatkan SBA (persamaan 3).

$$
\begin{gathered}
B C=0.04192 * \rho_{0} * h \\
S B A=F A A-B C
\end{gathered}
$$

Selanjutnya, pemetaan nilai SBA daerah penelitian dilakukan menggunakan software Surfer 16. Kemudian dilakukan pemisahan anomali residual dan regional dari SBA untuk melihat anomali bawah permukaan yang lebih jelas. Pemisahan anomali regional dari SBA dilakukan dengan menggunakan low pass filter $3 \times 3$. Low pass filter merupakan filter yang bekerja dengan meloloskan data berfrekuensi rendah dan menghilangkan data berfrekuensi tinggi sehingga didapatkan anomali regional. Untuk memperoleh anomali residual, dilakukan operasi matematika pada software surfer 16 dengan mengurangkan SBA dengan anomali regional.

Selanjutnya, Anomali residual dianalisis secara FHD dan SVD untuk melihat lebih jelas lagi struktur patahan dari anomali residual. Analisis anomali residual dengan FHD dapat menujukkan nilai perubahan anomali gravitasi secara horizontal untuk menentukan batas antara kontras densitas secara horizontal [1]. Perubahan anomali secara horizontal ditandai dengan nilai maksimum FHD pada grafik FHD. Oleh karena itu, nilai maksimum FHD merepresentasikan fitur geologi sesar [7]. Nilai FHD didapat dari persamaan 4.

$$
F H D=\sqrt{\left(\frac{\partial g}{\partial x}\right)^{2}+\left(\frac{\partial g}{\partial y}\right)^{2}}
$$

Analisis anomali residual dengan SVD dilakukan dengan menggunakan filter operasi matriks elkins (TABEL 1). SVD yang berfungsi sebagai high pass filter dengan meningkatkan efek dekat permukaan dan mengabaikan anomali yang lebih dalam. Oleh karena itu, hasil yang didapatkan berasosiasi dengan struktur dangkal [9]. Karena medan gravitasi memenuhi persamaan laplace, SVD dapat diperoleh dari turunan horizontal.

$$
\begin{aligned}
& \nabla^{2} g=\frac{\partial^{2} g}{\partial x^{2}}+\frac{\partial^{2} g}{\partial y^{2}}+\frac{\partial^{2} g}{\partial z^{2}}=0 \\
& \frac{\partial^{2} g}{\partial z^{2}}=-\left(\frac{\partial^{2} g}{\partial x^{2}}+\frac{\partial^{2} g}{\partial y^{2}}\right)
\end{aligned}
$$

SVD dapat digunakan untuk mengidentifikasi jenis patahan turun atau patahan naik [8]. Kriteria penentuan jenis patahan yaitu sebagai berikut:

$$
\begin{aligned}
& \left(\frac{\partial^{2} g}{\partial z^{2}}\right)_{m a k s}>\left.\left|\left(\frac{\partial^{2} g}{\partial z^{2}}\right)\right|\right|_{\min } \text { Patahan Normal } \\
& \left(\frac{\partial^{2} g}{\partial z^{2}}\right)_{m a k s}<\left.\left|\left(\frac{\partial^{2} g}{\partial z^{2}}\right)\right|\right|_{\min } \text { Patahan Naik }
\end{aligned}
$$


TABEL 1. Matriks Elkins (1951) (5x5) sebagai filter SVD

\begin{tabular}{|c|c|c|c|c|}
\hline 0 & -0.0833 & 0 & -0.0833 & 0 \\
\hline-0.0833 & -0.0667 & -0.0334 & -0.0667 & -0.0833 \\
\hline 0 & -0.0334 & 1.0668 & -0.0334 & 0 \\
\hline-0.0833 & -0.0667 & -0.0334 & -0.0667 & -0.0833 \\
\hline 0 & -0.0833 & 0 & -0.0833 & 0 \\
\hline
\end{tabular}

\section{HASIL DAN PEMBAHASAN}

Densitas batuan rata - rata yang diperoleh dengan metode parasnis sebesar $2.4454 \mathrm{gr} / \mathrm{cm}^{3}$. Berdasarkan nilai densitas tersebut, dapat diketahui bahwa batuan penyusun utama dari sesar weluki adalah batuan sedimen.

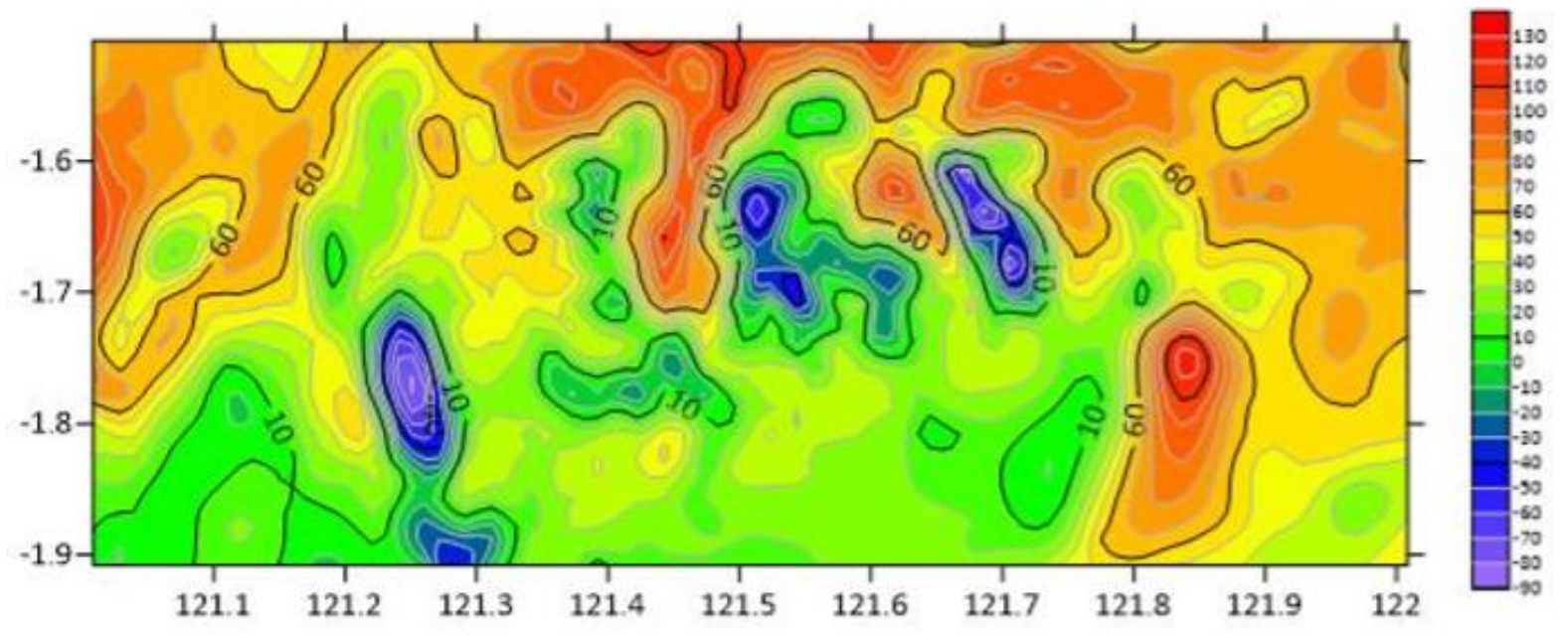

GAMBAR 2. Simple Bouguer Anomaly (SBA)

GAMBAR 2 menunjukkan hasil Anomali bouguer simple (SBA) yang didapat dari hasil pengolahan Free air anomali dan topografi menggunakan software surfer. Kontur SBA menunjukkan variasi densitas batuan bawah permukaan. Variasi nilai SBA yang didapat memiliki range sekitar -90 hingga 130. Berdasarkan kontur SBA, dapat dilihat bahwa anomali bouguer tertinggi ada pada daerah utara dan tenggara. Anomali bouguer terendah (biru) terletak di bagian dalam kontur hijau-kuning

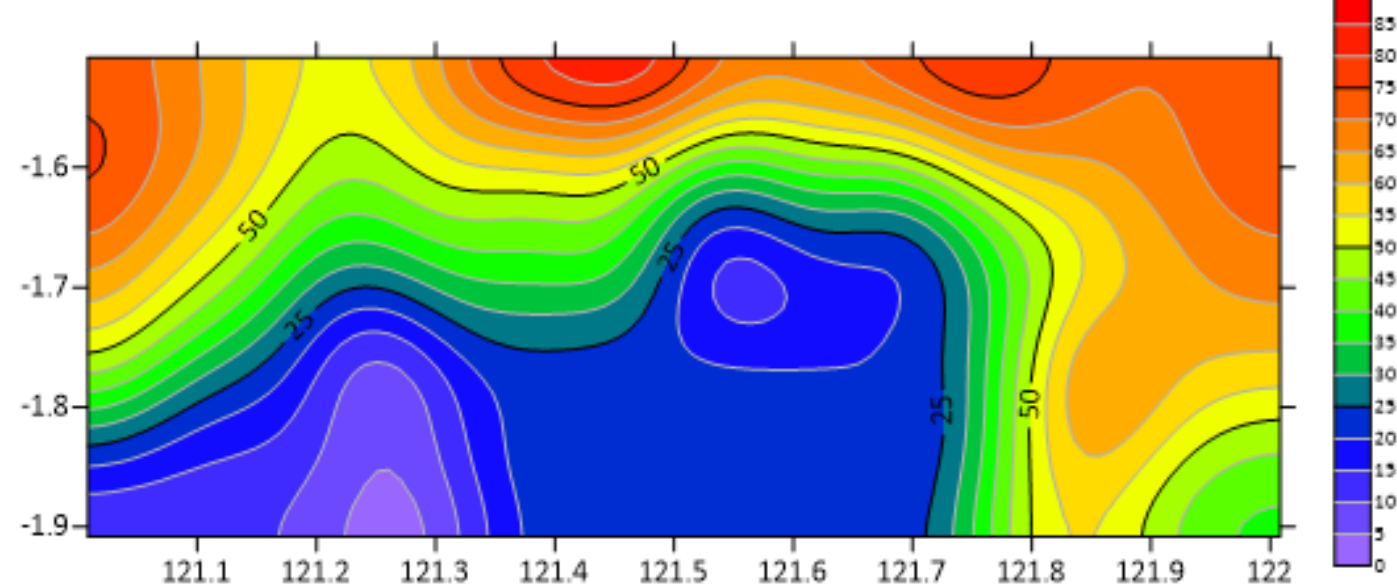

GAMBAR 3. Anomali Regional 


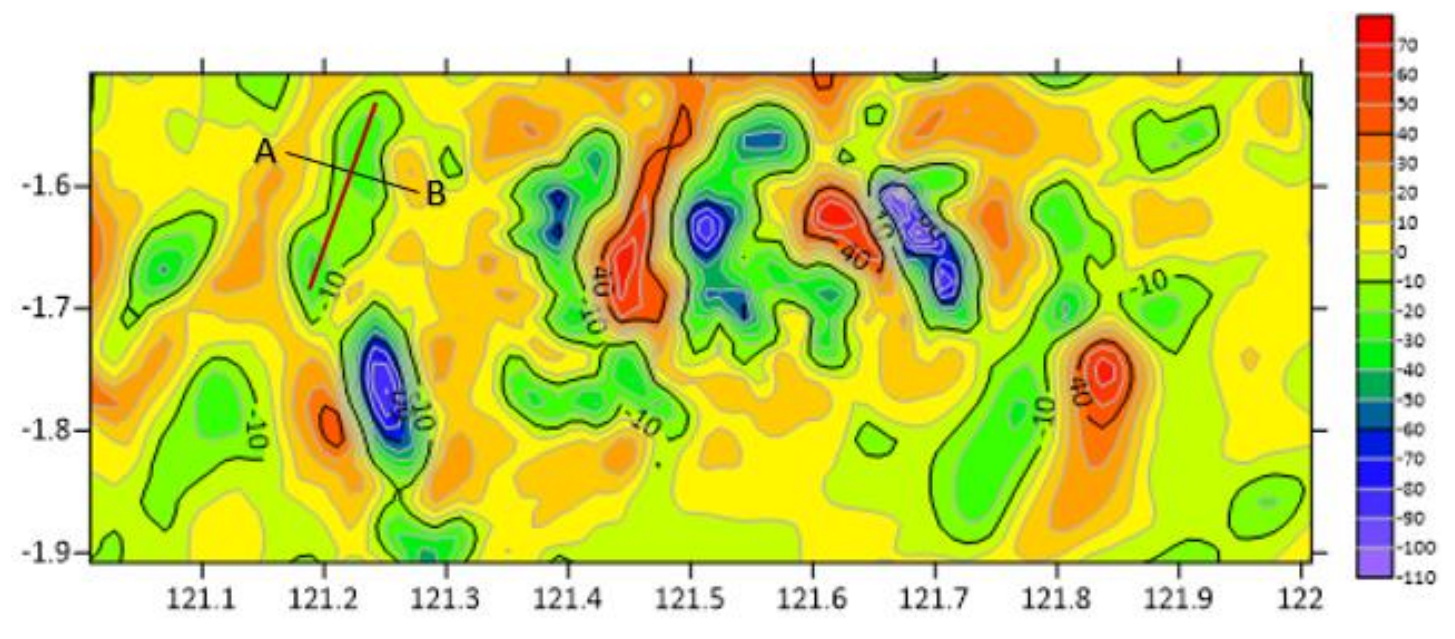

GAMBAR 4. Anomali Residual.

Pemisahan anomali regional dari SBA dilakukan dengan metode low filter $3 \times 3$. Setelah mendapatkan anomali regional, dilakukan pemisahan residual dengan mengurangkan SBA dengan anomali regional menggunakan program math di Surfer. Anomali residual pada GAMBAR 4 menunjukkan adanya keberadaan sesar. Letak posisi sesar berada diantara pertengahan nilai gravitasi minimum dan maksimum [4]. Oleh karena itu, garis AB diduga sebagai sesar weluki yang memiliki orientasi (strike) utara - selatan yang ditandai dengan garis merah.

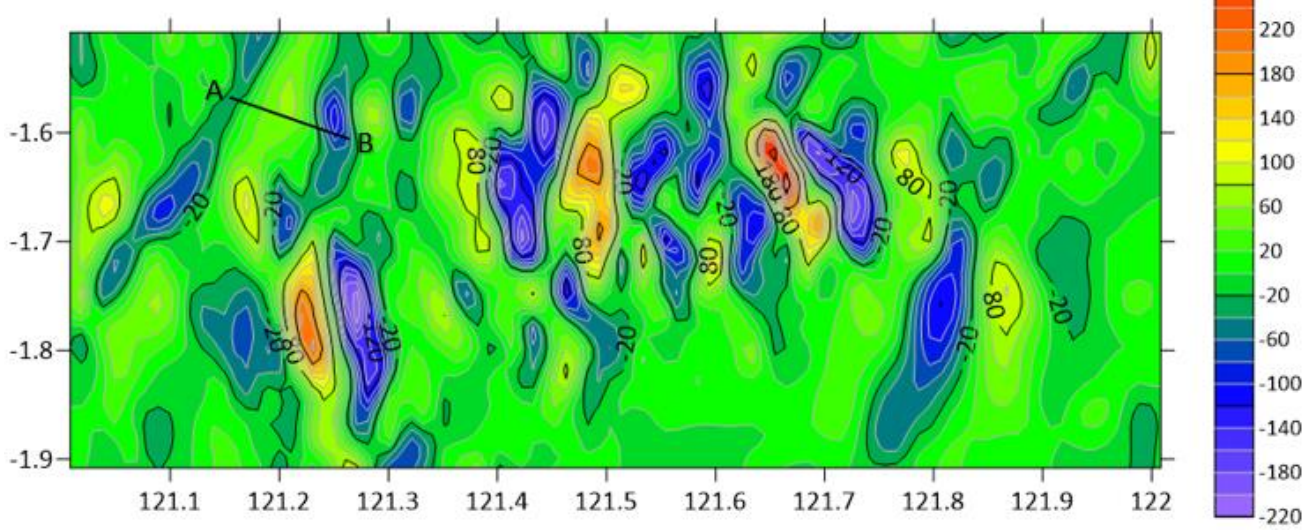

GAMBAR 5. Anomali residual hasil filter FHD 


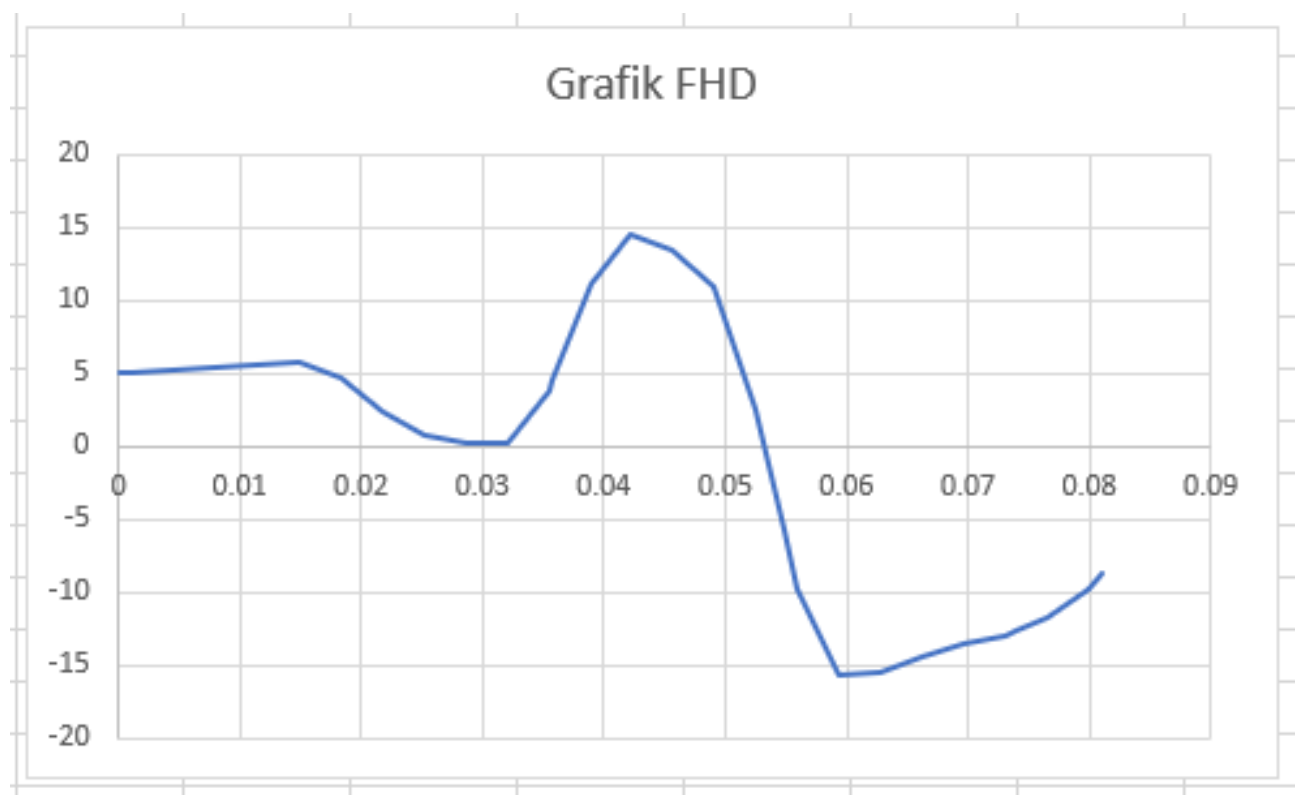

GAMBAR 6. Grafik nilai FHD pada irisan vertikal garis A-B

Selanjutnya, untuk memastikan lagi garis $\mathrm{AB}$ adalah sesar, maka dilakukan Analisa derivative FHD terhadap anomali residual dengan filter order 1st derivative prewitt Row Detector. Pada grafik FHD diatas, dapat dilihat bahwa nilai FHD maksimum atau tertinggi terletak pada nilai 14.53. Nilai maksimum pada grafik FHD menandakan adanya patahan dibawah permukaan. Perubahan nilai FHD dari rendah ke maksimal serta dari maksimal ke rendah lagi menunjukkan border (batas) perbedaan densitas batuan secara lateral yang disebabkan oleh adanya perbedaan litologi. Perbedaan litologi dibawah permukaan salah satunya terjadi karena adanya sesar baik itu sesar naik atau sesar turun.

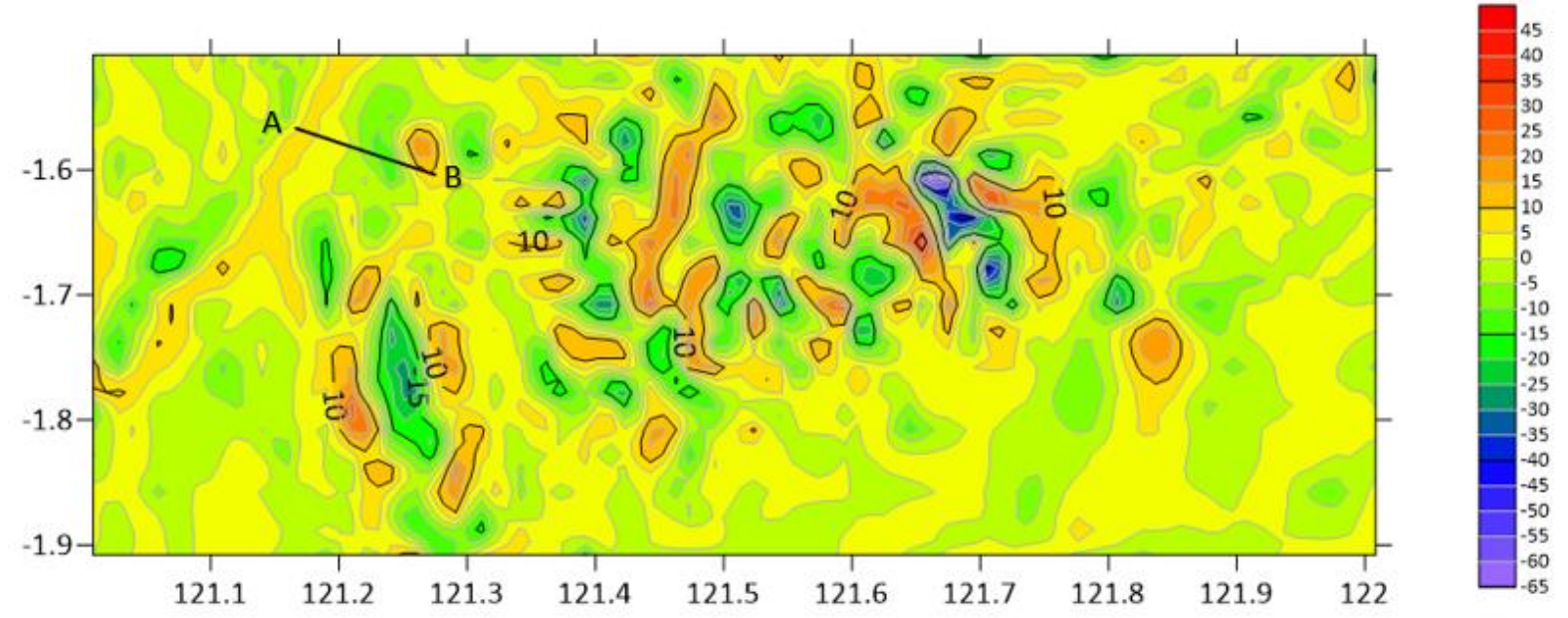

GAMBAR 7. Anomali residual hasil filter SVD 


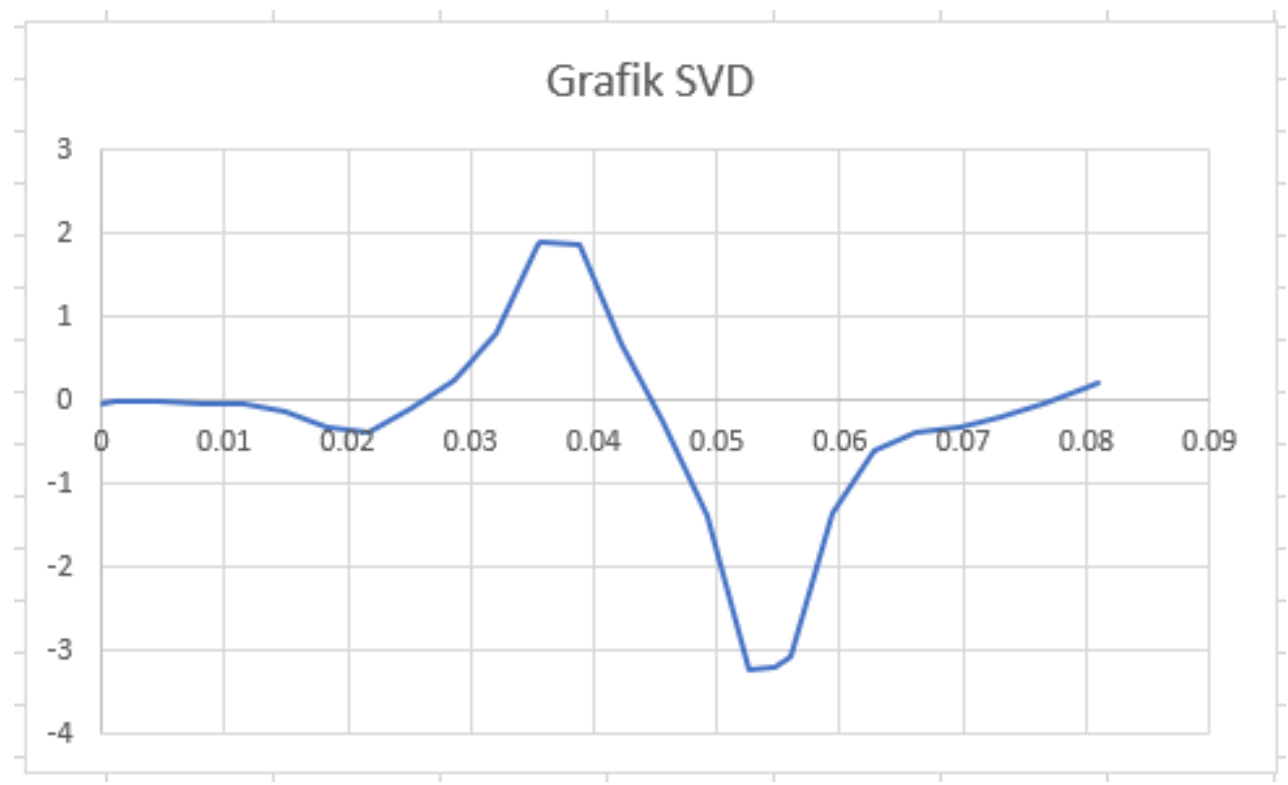

GAMBAR 8. Grafik nilai SVD pada irisan vertikal garis A-B.

Selain melakukan Analisa FHD terhadap data residual, Analisa SVD dengan filter matriks elkins juga perlu dilakukan untuk mengetahui tipe atau jenis sesar Weluki. Berdasarkan grafik svd tersebut, dapat dilihat bahwa nilai tertinggi SVD sebesar 1.89 dan nilai terendah SVD sebesar -3.218. Ketika nilai minimum dihargai mutlak, nilai minimum akan lebih besar dibandingkan dengan nilai maksimum $(3.218>1.89)$. Berdasarkan persamaan 7 , sesar weluki memenuhi kriteria sebagai patahan naik. Oleh karena itu, Sesar Weluki termasuk jenis sesar atau patahan naik.

\section{KESIMPULAN}

Dari hasil penelitian dapat disimpulkan bahwa anomali sesar Weluki yang ada di Sulawesi Tengah berhasil diidentifikasi dengan menggunakan data topografi dan gravitasi dari TOPEX. Anomali yang terindikasi sebagai Sesar Weluki memiliki orientasi strike Utara - Selatan. Sesar Weluki merupakan jenis sesar naik, dilihat dari harga mutlak nilai minimum SVD yang lebih besar dari nilai maksimum SVD.

\section{UCAPAN TERIMAKASIH}

Penulis mengucapkan terimakasih kepada TOPEX atas data yang diberikan. Selanjutnya para pengajar di Geosains Universitas Indonesia yang telah mengajarkan cara pengolahan data gravitasi.

\section{REFERENSI}

[1] L. Cordell, "Gravimetric Expression of Graben Faulting," in Santa Fe Country and The Espanola Basin, New Mexico: New Mexico, Geol. Sot. Guidbook, 30th Field Conf, pp. 5964, 1979.

[2] R. Hall, M. A. Cottam \& M. E. J. Wilson, "The SE Asian Gateway: History and Tectonics of the Australia-Asia Collision. Geological Society," London, Special Publications, vol. 355, pp. 1-6, 2013, DOI: 10.1144/SP355.1 0305-8719/11/\$15.00.

[3] M. S. Kaharuddin, R. Hutagalung \& Nurhamdan, "PERKEMBANGAN TEKTONIK DAN IMPLIKASINYA TERHADAP POTENSI GEMPA DAN TSUNAMI DI KAWASAN PULAU SULAWESI," The 36th HAGI and 40th IAGI Annual Convention and Exhibition, pp. 1-5, 2011. 
[4] Nurwidianto Irham et al., "Study Pendahuluan Sesar Opak Dengan Metode Gravity (Study Kasus Daerah Sekitar Kecamtan Pleret Bantul)," in Jurnal Berkala Fisika, Yogyakarta, vol. 14, no. 1, pp. 11-16, 2011.

[5] P. Kearey, M. Brooks and I. Hill, "Gravity Surveying" in An Introduction to Geophysical Exploration, 3rd ed. New Jersey: BS, pp. 125-137, 2002.

[6] Pusat Studi Gempa Nasional Kementerian PUPR, "Tektonik Sulawesi” in PETA SUMBER DAN BAHAYA GEMPA INDONESIA TAHUN 2017, Bandung: Pusat Litbang Perumahan dan Permukiman Balitbang Kementerian PUPR Republik Indonesia, 2017.

[7] R. J. Blakely, "Transformations," in Potential Theory in Gravity and Magnetic Applications, Cambridge: CUP, 1996, pp. 347-350

[8] Sriyanto et al., "IDENTIFIKASI PATAHAN MIKRO PENYEBAB GEMPA BUMI TARAKAN 21 DESEMBER 2015," in Seminar Nasional Fisika, Jakarta, 2016.

[9] W. M. Telford, L. P. Geldart and R. E. Sheriff, "Gravity Methods," in Applied Geophysics, 2nd ed, Cambridge: CUP, pp. 10-32, 1990. 